ACTA UNIVERSITATIS WRATISLAVIENSIS

PRZEGLĄD PRAWA I ADMINISTRACJI CXX/1

WROCŁAW 2020

https://doi.org/10.19195/0137-1134.120.49

\author{
WIESŁAWA MIEMIEC \\ ORCID: 0000-0001-8472-2200 \\ Uniwersytet Wrocławski \\ Katedra Prawa Finansowego
}

\title{
ROZSZERZENIE ŹRÓDEŁ FINANSOWANIA DEFICYTU BUDŻETU JEDNOSTEK SAMORZĄDU TERYTORIALNEGO
}

\begin{abstract}
Abstrakt: Normatywne pojęcie deficytu budżetowego j.s.t. zostało określone expressis verbis w art. 217 ust. 1 ustawy o finansach publicznych. Zgodnie z powołanym przepisem jest to ujemna różnica pomiędzy dochodami a wydatkami w konkretnym roku budżetowym. Ustawodawca jednocześnie wymaga, aby w uchwale budżetowej przewidującej w danym roku deficyt wskazano źródła jego spłaty. Reglamentacji prawnej podlega zatem nie tylko wysokość deficytu budżetowego j.s.t. i ograniczenia pozyskiwania środków finansowych kreujących ten deficyt, lecz także źródła i sposób jego finansowania. Ustawa z dnia 14 grudnia 2018 roku o zmianie ustawy o finansach publicznych wprowadziła wiele zmian w systemie finansów j.s.t., w tym również zwiększony został katalog źródeł finansowania deficytu. Przedmiotem tego opracowania jest ocena istotnego fragmentu wprowadzonych zmian dotyczących tych nowych źródeł finansowania deficytu budżetu j.s.t. Najistotniejszą rolę $\mathrm{w}$ tym zakresie odgrywają przychody $\mathrm{z}$,niewykorzystanych środków pieniężnych na rachunku bieżącym budżetu, wynikające z rozliczania dochodów i wydatków nimi finansowanych, związanych ze szczególnymi zasadami wykonywania budżetu określonymi w odrębnych ustawach". Ustawodawca nie zdefiniował terminu „szczególne zasady wykonywania budżetu” ani też nie wskazał, o jakie odrębne ustawy chodzi. Istotne jest zatem ustalenie tych zagadnień. W artykule wskazany został przykładowy katalog takich ustaw. Ustalenia te będą miały istotne znaczenie dla dalszego stosowania znowelizowanych przepisów ustawy o finansach publicznych.
\end{abstract}

Słowa kluczowe: dochody budżetu jednostek samorządu, przychody budżetu j.s.t., deficyt budżetowy, źródła finansowania deficytu, wolne środki w ewidencji budżetowej

\section{UWAGI WPROWADZAJĄCE}

Jednostki samorządu terytorialnego (dalej: j.s.t.) w celu realizacji zadań wyposażono nie tylko we własny majątek (mienie komunalne), ale przyznano im ustawowo odrębne źródła dochodów. W świetle standardów wynikających zarów- 
no z Europejskiej Karty Samorządu Terytorialnego ${ }^{1}$, jak i konstytucyjnej zasady odpowiedniości ${ }^{2}$ środki pieniężne pozyskiwane z tych źródeł powinny umożliwić j.s.t. finansowanie wydatków służących realizacji przypadających im zadań. Tylko taka relacja pomiędzy wysokością posiadanych środków a zakresem zadań może j.s.t. zapewnić samodzielne prowadzenie własnej gospodarki finansowej. Kluczową instytucją gospodarki finansowej j.s.t. jest ich budżet uchwalany corocznie przez organ stanowiący będący podstawą ich samodzielnej gospodarki finansowej. Ustawodawca nakłada zatem na j.s.t. wymóg prowadzenia gospodarki na podstawie uchwały budżetowej ${ }^{3}$. Tym samym obowiązujące przepisy statuują budżet (będący najważniejszą częścią uchwały budżetowej) jako podstawowy plan samodzielnej gospodarki finansowej j.s.t. Podstawowy charakter budżetu wynika z jego struktury, zakresu przedmiotowego i podmiotowego, a także z trybu i formy prawnej związanej z jego uchwaleniem, ogłoszeniem i wykonywaniem. Ten szczególny charakter budżetu zdeterminowany jest przez zasady budżetowe. Oprócz zasady powszechności, jedności, a także jawności i przejrzystości, istotną rolę odgrywa również zasada równowagi budżetowej.

Klasyczne rozumienie zasady równowagi budżetowej nakazuje pełne pokrycie wydatków zaplanowanych w budżecie dochodami osiągniętymi w danym roku budżetowym. Zachowanie tego postulatu eliminuje możliwość uchwalenia budżetu deficytowego. Współczesne rozumienie tej zasady w systemie finansów publicznych odbiega jednak od jej pierwotnego ujęcia. Obecnie obowiązujące przepisy dopuszczają możliwość uchwalenia budżetu j.s.t., którego planowane wydatki będą wyższe niż planowane dochody $-\mathrm{z}$ jednoczesnym obowiązkiem określenia w uchwale budżetowej kwoty planowanego deficytu wraz ze źródłami jego pokrycia (art. 212 ust. 1 pkt 3 u.f.p.). Normatywne pojęcie deficytu budżetowego j.s.t. zostało określone expressis verbis w art. 217 ust. 1 u.f.p. Zgodnie z powołanym przepisem ujemna różnica pomiędzy dochodami a wydatkami tego budżetu stanowi deficyt budżetowy. Pojęcie prawne deficytu odnosi się więc tylko do określonego roku budżetowego. Natomiast dług publiczny, w tym także dług j.s.t., to zbiorcza kategoria odnosząca się do wszelkich zobowiązań, które zostały skumulowane w poprzednich przedziałach czasowych. Podstawowymi przyczynami powstawania długu j.s.t. są przede wszystkim ich skumulowane deficyty budżetowe. Ustawowy wymóg wskazania w uchwale budżetowej źródeł pokrycia zaplanowanego deficytu upoważnia do stwierdzenia, że nie tylko na etapie planowania, ale również na etapie uchwalania i wykonywania budżetu wymaga się za-

1 Oświadczenie rządowe z 14 lipca 1994 roku w sprawie ratyfikacji przez Rzeczpospolitą Polską Europejskiej Karty Samorządu Terytorialnego sporządzonej 15 października 1985 roku w Strasburgu, Dz.U. z 1994 r. Nr 124, poz. 608.

2 Art. 167 ust. 1 ustawy Konstytucji Rzeczypospolitej Polskiej z 2 kwietnia 1997 roku, Dz.U. $\mathrm{Nr} 78$, poz. 483 ze zm.

3 Art. 211 ust. 4 ustawy z dnia 27 sierpnia 2009 roku o finansach publicznych, tekst jedn. Dz.U z 2019 r. poz. 869 ze zm., dalej: u.f.p. 
bezpieczenia w środki finansowe w celu realizacji zaplanowanych wydatków niemających pokrycia w planowanych dochodach. Można więc przyjąć, że obecnie ukształtowana zasada równowagi budżetowej na wszystkich etapach procedury wymaga prawidłowego planowania i uchwalania dochodów, wydatków oraz przychodów i rozchodów, a także realnej oceny wydajności fiskalnej źródeł dochodów i przychodów z uwzględnieniem konieczności zrównoważenia budżetów. Proces ten przebiega $\mathrm{w}$ formach zinstytucjonalizowanych, regulowanych prawem finansów publicznych. Podstawowym celem determinacji prawnej jest więc ustalenie bezpiecznych granic zadłużenia dla podmiotów publicznych.

\section{NORMATYWNY KATALOG ŹRÓDEŁ FINANSOWANIA DEFICYTU BUDŻETU J.S.T.}

Reglamentacji prawnej podlega nie tylko wysokość deficytu budżetowego j.s.t. i ograniczenia pozyskiwania środków finansowych kreujących ten deficyt, lecz także źródła i sposób jego finansowania. Wymogi, które według obowiązujących przepisów muszą zostać spełnione przez j.s.t., aby skorzystać z instrumentów umożliwiających zrównoważenie budżetu w sytuacji, kiedy planowana kwota wydatków nie może być pokryta planowanymi dochodami tego budżetu, są bardzo rygorystyczne. Istotną rolę $\mathrm{w}$ tym zakresie należy przypisać przede wszystkim konieczności finansowania planowanego deficytu budżetu j.s.t. wyłącznie środkami finansowymi pozyskanymi ze źródeł wskazanych ustawowo. Zamknięty katalog tych źródeł został określony w przepisie art. 217 ust. 2 u.f.p. Ustawodawca źródła te kwalifikuje jako przychody i przednio wymieniał ich sześć. Według stanu prawnego obowiązującego do 31 grudnia 2018 roku deficyt j.s.t. mógł być pokryty przychodami ze sprzedaży papierów wartościowych wyemitowanych przez jednostkę, z zaciągniętych kredytów i pożyczek, z prywatyzacji majątku j.s.t., z nadwyżki budżetowej z lat ubiegłych oraz tak zwanymi wolnymi środkami będącymi nadwyżką środków pieniężnych na rachunku bieżącym budżetu wynikającą z rozliczeń wyemitowanych papierów wartościowych, kredytów i pożyczek z lat ubiegłych. Jak wynika $z$ tego wyliczenia, oprócz środków zwrotnych, których pozyskanie wiąże się z koniecznością ich oddania wraz z oprocentowaniem, występują tu także tak zwane inne rodzajowo źródła. Do tej grupy należy zaliczyć przychody będące rezultatem pomniejszenia składników mienia komunalnego w wyniku ich prywatyzacji czy też nadwyżkę budżetową z lat ubiegłych zwaną nadwyżką skumulowaną, jak i wolne środki stanowiące nadwyżki na rachunku bieżącym wynikające $\mathrm{z}$ rozliczeń z lat ubiegłych z tytułów wskazanych w tym przepisie. Ostatnie źródło przychodów, ,źródła wyliczalne”, powodowało wiele komplikacji praktycznych związanych z identyfikowaniem rozliczeń przepływów pochodzących z tych zróżnicowanych źródeł. Powodowało to konieczność odręb- 
nego ich traktowania. Sytuacja ta była konsekwencją braku precyzyjnej weryfikacji tej kategorii przychodów. Jak wskazuje się w literaturze, w praktyce sprzyjało to niegospodarnemu pozyskiwaniu dodatkowej kwoty wolnych środków poprzez zaciągnięcie zobowiązania finansowego na pokrycie celowo przeszacowanego deficytu budżetu j.s.t. ${ }^{4}$

Ustawa z dnia 14 grudnia 2018 roku o zmianie ustawy o finansach publicznych $^{5}$ wprowadziła wiele istotnych zmian w systemie finansów samorządu terytorialnego - doprecyzowano ustawowy katalog tytułów dłużnych zaliczanych do długu publicznego, powiększono katalog źródeł finansowania deficytu budżetu j.s.t. i zmieniono zasady bilansowania części operacyjnej (bieżącej) budżetu j.s.t. Przedmiotem dalszego opracowania jest ocena istotnego fragmentu wprowadzonych zmian dotyczących nowych źródeł finansowania deficytu budżetu j.s.t.

\section{NOWE ŹRÓDŁA FINANSOWANIA DEFICYTU BUDŻETU J.S.T.}

Według uzasadnienia projektu ustawy nowelizującej wprowadzone zmiany miały zmierzać do zracjonalizowania możliwości zadłużania samorządów terytorialnych, uelastycznienia ich gospodarki finansowej oraz wzmocnienia mechanizmów prawnych służących zwiększeniu ich bezpieczeństwa finansowego. Wprowadzone przepisy — oprócz zmiany zasad zaciągania zobowiązań dłużnych zaliczanych do długu publicznego - korygują sposób ustalania maksymalnego wskaźnika spłaty zobowiązań, wprowadzają także nowe kompetencje organów wykonawczych j.s.t. do dokonywania zmian w budżecie oraz $\mathrm{w}$ treści wieloletniej prognozy finansowej, a także ustanawiają nowy katalog źródeł finansowania deficytu budżetu j.s.t. Ustawa, co do zasady, weszła w życie z dniem 1 stycznia 2019 roku. Niektóre jej przepisy miały jednak zastosowanie po raz pierwszy do opracowania i wykonywania budżetu j.s.t. na rok 2020 (art. 8 ust. 1ustawy nowelizującej), a inne do opracowania i wykonania budżetu j.s.t. i wieloletniej prognozy finansowej j.s.t. na rok 2022 (art. 8 ust. 2 ustawy nowelizującej).

Zgodnie z art. 1 ust. 5 ustawy nowelizującej w treści art. 217 wprowadzono następujące zmiany.

Ust. 2 pkt 5 tego przepisu otrzymał brzmienie: ,nadwyżki budżetu jednostki samorządu terytorialnego z lat ubiegłych, pomniejszonej o środki określone w pkt 8".

W pkt. 6 kropkę zastąpiono średnikiem i dodano pkt 7 i 8 w następującym brzmieniu:

— pkt 7 ,spłaty udzielonych pożyczek z lat ubiegłych”,

— pkt 8: ,niewykorzystanych środków pieniężnych na rachunku bieżącym budżetu, wynikających z rozliczania dochodów i wydatków nimi finansowanych

\footnotetext{
${ }^{4}$ P. Walczak, M. Woźniak, Zmiany w finansach publicznych 2019, Warszawa 2019, s. 46.

5 Dz.U. z 2018 r. poz. 2500, dalej: ustawa nowelizacyjna.
} 
związanych ze szczególnymi zasadami wykonywania budżetu określonymi w odrębnych ustawach oraz wynikających z rozliczenia środków określonych w art. 5 ust. 1 pkt 2 i dotacji na realizację programu, projektu lub zadania finansowanego $\mathrm{z}$ udziałem tych środków 6 .

Poprzedni katalog wskazujący sześć źródeł przychodów, które mogły być przeznaczone na finansowanie deficytu budżetu j.s.t. został zatem wzbogacony. W stosunku do przedstawionych źródeł dodano dalsze, a mianowicie przychody:

— uzyskane w wyniku spłaty pożyczki udzielonej z budżetu j.s.t. w latach ubiegłych (art. 217 ust. 2 pkt 7 u.f.p.),

— z niewykorzystanych środków pieniężnych na rachunku bieżącym budżetu j.s.t. wynikających z rozliczenia dochodów i wydatków nimi finansowanych związanych ze szczególnymi zasadami wykonania budżetu określonymi w odrębnych ustawach, oraz

- wynikające $z$ rozliczenia środków określonych w art. 5 ust. 1 pkt 2 u.f.p. i dotacji na realizację programu, projektu lub zadania finansowanego $\mathrm{z}$ udziałem tych środków (art. 217 ust. 2 pkt 8 u.f.p.).

Patrząc na rodzaje dodanych źródeł przychodu, które mogą służyć finansowaniu deficytu budżetu j.s.t., należy wskazać na ich zróżnicowanie prawne. Występują tutaj środki pieniężne pochodzące $\mathrm{z}$ lat ubiegłych, mające pierwotnie status zarówno dochodów, jak i przychodów.

Do środków, które od momentu ich otrzymania mają status przychodów, należy zaliczyć środki pozyskane z tytułu spłaty pożyczki udzielonej z budżetu j.s.t. w latach ubiegłych. Wcześniejsze nieuwzględnienie możliwości wykorzystania takich środków do pokrycia deficytu budżetu j.s.t. było nieuzasadnione. Obecnie j.s.t. będą mogły finansować ujemną różnicę pomiędzy dochodami a wydatkami budżetu j.s.t. kwotą ustaloną dla określonego okresu rozliczeniowego także ze środków wyżej wskazanych.

Innymi rodzajowo odmiennymi źródłami finansowania deficytu budżetu j.s.t. są przychody wskazane w treści art. 217 ust. 2 pkt 8 u.f.p. Ustawodawca wymienia w tym przepisie jeden rodzaj przychodów, które pochodzą z dwóch różnych tytułów. W pierwszej kolejności deficyt budżetu j.s.t. może być finansowany przez niewykorzystane środki pieniężne na rachunku bieżącym budżetu j.s.t. wynikające z rozliczenia dochodów i wydatków nimi finansowanych na podstawie szczególnych zasad wykonania budżetu określonych w odrębnych ustawach. Niestety w przepisach ustawy nie został zdefiniowany sposób rozumienia ,szczególnych zasad wykonania budżetu j.s.t." i obowiązujący w tym zakresie „sposób rozliczenia dochodów dla finansowania określonych wydatków". Zapewne chodzi tutaj o środki, które stanowiąc wyjątek od budżetowej zasady jedności materialnej na podstawie odrębnych

${ }^{6}$ Ustawa z dnia 27 sierpnia 2009 roku o finansach publicznych, tekst jedn. Dz.U z 2019 r. poz. 869 ze zm., dalej: u.f.p. 
ustaw, będą mogły być wykorzystywane na finansowanie imiennie wymienionych wydatków ${ }^{7}$. W literaturze wskazywano, że dużym problemem dla czytelności realizacji budżetu j.s.t. był brak wyraźnego rozgraniczenia pomiędzy środkami pozyskiwanymi zgodnie z zasadą jedności materialnej (bez określonego celu przeznaczenia) a środkami pozyskiwanymi na zasadzie wyjątku od tej zasady, czyli powiązanymi ze ściśle określonym celem wydatku. Kwota środków pieniężnych z celowym przeznaczeniem wpływała na wielkość wykonania budżetu ogółem, z jednoczesnym zniekształceniem jego rzeczywistego wyniku. Rozszerzenie przez ustawodawcę źródeł finansowania deficytu o przychody wynikające z rozliczenia dochodów i wydatków nimi finansowanych związanych ze szczególnymi zasadami wykonania budżetu oznacza, że środki takie (o ile nie zostaną wydatkowane do końca roku budżetowego i pozostaną na rachunku bieżącym budżetu j.s.t. $\mathrm{w}$ dniu 31 grudnia roku budżetowego), w treści nowego budżetu zostaną wprowadzone jako przychody, które będą mogły służyć finansowaniu deficytu budżetu j.s.t., powstałemu w związku z koniecznością realizacji wydatków ze środków stanowiących dochody w roku poprzednim.

Powstaje jednak uzasadnione pytanie, jakie ustawy należy zakwalifikować do kategorii tych, które ustanawiają szczególne zasady wykonywania budżetu. Ustawodawca niestety również nie wskazał takiego katalogu. Ustalenie zakresu przedmiotowego tego katalogu jest jednak niezmiernie ważnym zagadnieniem, nie tylko dla regionalnych izb obrachunkowych w związku z wykonywaniem kompetencji nadzorczych, ale także dla poszczególnych j.s.t. w celu racjonalnego wykorzystania pojawiających się nowych możliwości pokrywania planowanego deficytu. Krajowa Rada RIO podjęła w związku z nowy brzmieniem art. 217 ust. 2 pkt 8 u.f.p. pracę w kierunku ustalenia katalogu ustaw wymuszających szczególne zasady wykonania budżetu. Nie został jednak opublikowany żaden rezultat tych prac. Analizując materialnoprawne przepisy, można pokusić się o wskazanie kilku takich przykładów.

Koronnym przykładem będzie tutaj obowiązująca już od 1982 roku ustawa o wychowaniu w trzeźwości i przeciwdziałaniu alkoholizmowi ${ }^{8}$. Dochody z opłat, o których mowa w art. $18,18^{1 \mathrm{a}}$ i $11^{1}$ ustawy, za zezwolenia wydane na przez wójta (burmistrza, prezydenta miasta), właściwego ze względu na lokalizację punktu sprzedaży, na sprzedaż napojów alkoholowych przeznaczonych do spożycia w miejscu lub poza miejscem sprzedaży, mogą być (według art. $18^{2}$ ustawy) wykorzystywane na realizację gminnych programów profilaktyki i rozwiązywania problemów alkoholowych oraz gminnych programów przeciwdziałania narkoma-

${ }^{7}$ Art. 42 ust. 2 u.f.p. zasady jedności materialnej stanowi, że środki publiczne pochodzące z poszczególnych tytułów nie mogą być przeznaczane na finansowanie imiennie wymienionych wydatków, chyba że odrębna ustawa stanowi inaczej.

${ }^{8}$ Ustawa z dnia 26 października 1982 roku o wychowaniu w trzeźwości i przeciwdziałaniu alkoholizmowi, tekst jedn. Dz.U. z 2019 r. poz. 2277 ze zm. 
nii ${ }^{9}$, a także zadań realizowanych przez placówkę wsparcia dziennego, o której mowa w przepisach o wspieraniu rodziny i systemie pieczy zastępczej ${ }^{10}$. Ustawa przewiduje tez, że opłaty, o których mowa w art. $9^{2}$ ustawy, mogą być przez zarząd województwa przeznaczone wyłącznie na zadania wskazane $\mathrm{w}$ art. $9^{3}$, to jest na finansowanie:

— zadań określonych w art. 4 ust. 1 ustawy,

— zadań określonych w Wojewódzkim Programie, o którym mowa w art. 9 ust. 1 ustawy o przeciwdziałaniu narkomanii,

— zadań realizowanych przez placówkę wsparcia dziennego, o której mowa w przepisach o wspieraniu rodziny i systemie pieczy zastępczej w ramach wojewódzkich programów profilaktyki i rozwiązywania problemów alkoholowych.

$\mathrm{W}$ świetle nowego brzmienia art. 217 ust. 2 pkt 8 u.f.p. niewykorzystane $\mathrm{w}$ danym roku budżetowym dochody budżetowe pochodzące $\mathrm{z}$ opłat wyżej wskazanych uzyskają w nowym budżecie status przychodów i będą nowym źródłem finansowania deficytu budżetu gmin lub województwa samorządowego.

Innym przykładem ustawy przewidującej szczególne zasady wykonywania budżetu jest ustawa o utrzymaniu czystości i porządku $\mathrm{w}$ gminach ${ }^{11}$. Zgodnie $\mathrm{z}$ art. 6r ust. 1ab środki pochodzące z opłat za gospodarowanie odpadami komunalnymi odpowiednio gmina lub związek międzygminny gromadzą na wyodrębnionym rachunku bankowym. Według art. 6r ust.1aa ustawy opłaty za gospodarowanie opłatami komunalnymi nie mogą być wykorzystane na cele niezwiązane z pokrywaniem kosztów funkcjonowania systemu gospodarowania odpadami komunalnymi. Koszty funkcjonowania tego systemu zostały wskazane w art. 6r ust. 2 ustawy. W stanie prawnym, który ma zastosowanie do opracowania i wykonania budżetu j.s.t. na rok 2020, otrzymane dochody pochodzące ze wskazanych źródeł, niewydatkowane na pokrycie kosztów funkcjonowania systemu gospodarowania odpadami, zmieniają swój pierwotny status i jako przychody uzyskują przeznaczenie określone w treści art. 217 ust. 2 pkt 8 u.f.p. w związku z koniecznością ponoszenia wydatków na cele wskazane w ustawie o utrzymaniu czystości i porządku w gminach.

Do ustaw kreujących szczególne zasady wykonywania budżetu j.s.t., należy zaliczyć także ustawę prawo ochrony środowiska, wskazująca konkretne zadania gmin i powiatów, które mogą być finansowane z wpływów uzyskanych z tytułu opłat i kar wskazanych w art. 402 ust. 4, 5 i 6 ustawy ${ }^{12}$. Według powołanego przepisu ustawy wpływy z tytułu opłat i kar stanowiących dochody budżetu powiatu

9 Art. 10 ust. 2 ustawy z dnia 29 lipca 2005 roku o przeciwdziałaniu narkomanii, tekst jedn. Dz.U. z 2019 r., poz. 852 ze zm.

10 Ustawa z dnia 9 czerwca 2011 roku, tekst jedn. Dz.U. z 2019 r. poz. 1111 ze zm.

11 Ustawa z dnia 13 września 1996 roku o utrzymaniu czystości i porządku w gminach, tekst jedn. Dz.U. z 2019 r. poz. 2010 ze zm.

12 Ustawa z dnia 27 kwietnia 2001 roku Prawo ochrony środowiska, tekst jedn. Dz.U. z 2019 r. poz. 1396 ze zm. 
mogą być przeznaczane wyłącznie na finansowanie zadań w zakresie ochrony środowiska określonych $\mathrm{w}$ art. 400a ust. 1 pkt 2, 5, 8, 9, 15, 16, 18, 21-25, 29, 31, 32 i 38-42 w wysokości nie mniejszej niż kwota wpływów z tytułu tych opłat i kar pomniejszona o nadwyżkę z tytułu tych dochodów przekazywaną do wojewódzkich funduszy. W wypadku budżetów gmin chodzi o obowiązek przeznaczenia wpływów z tytułu opłat i kar, o których mowa w art. 402 ust. 4, 5 i 6 , stanowiących dochody budżetów gmin pomniejszone o nadwyżkę z tytułu tych dochodów przekazywaną do wojewódzkich funduszy, które mogą być przeznaczone wyłącznie na finansowanie zadań ochrony środowiska w zakresie określonym w art. 400a ust. 1 pkt 2, 5, 8, 9, 15, 16, 21-25, 29, 31, 32 i 38-42. Także i tutaj otrzymane w konkretnym roku budżetowym dochody budżetu gminy lub powiatu z tytułu opłat i kar, na przykład za składowanie odpadów, o ile nie zostaną w danym roku wydatkowane na finansowanie wskazanych powyżej zadań, w kolejnym roku budżetowym jako przychody — będą mogły służyć finansowaniu deficytu budżetu tej gminy lub powiatu.

Szczególne zasady wykonywania budżetów j.s.t. zostały przewidziane także w przepisach ustawy o ochronie gruntów rolnych i leśnych ${ }^{13}$. Dochody związane $\mathrm{z}$ wyłączeniem z produkcji gruntów rolnych stanowią niepodatkowe należności budżetu województwa o charakterze publicznoprawnym w rozumieniu u.f.p. (art. 22 b ust. 1 i 3). Zarząd województwa gromadzi te dochody na wyodrębnionym rachunku bankowym (art. 22b ust. 2). Według art. 22b dochodami budżetu województwa są (pobierane na podstawie ustawy należności) opłaty roczne, opłaty z tytułu niewykonania obowiązku zdjęcia i wykorzystania próchnicznej warstwy gleby, opłaty oraz należności i opłaty roczne podwyższone określone w art. 28 ust. 1-4, a także odsetki z tytułu należności i opłat, o których mowa w pkt. 1-4. Dochody te w zakresie ustalonym w ustawie muszą służyć finansowaniu zadań polegających na ochronie, rekultywacji i poprawie jakości gruntów rolnych oraz wypłacie odszkodowań przewidzianych ustawą. Otwarty katalog tych zadań jest sformułowany w art. 22c ust. 1 ustawy. Ustawodawca wymienił tutaj między innymi konieczność przeznaczenia ich na rekultywację na cele rolnicze gruntów, które utraciły lub zmniejszyły wartość użytkową wskutek działalności nieustalonych osób, na rolnicze zagospodarowanie gruntów zrekultywowanych, budowę i renowację zbiorników wodnych służących małej retencji czy też budowę i modernizację dróg dojazdowych do gruntów rolnych. Według art. 22c ust. 2 dochody te powinny być w pierwszej kolejności przeznaczane na wykonywanie prac wymienionych w ust. 1 na obszarze tych gmin, w których powstają te dochody oraz istnieją warunki uzyskania wzrostu produkcji rolniczej, rekompensującej straty poniesione w wyniku zmniejszenia obszaru gruntów rolnych. Tutaj również niewykorzystane dochody na rachunku bieżącym województwa, pochodzące ze

13 Ustawa z dnia 3 lutego 1995 roku o ochronie gruntów rolnych i leśnych, tekst jedn. Dz.U. z 2017 r. poz. 1161 ze zm. 
źródeł wskazanych w art. 22b ustawy, które nie zostały wykorzystane przez zarząd województwa w konkretnym roku budżetowym na zadania wskazane w art. 22c ust. 1 ustawy, powodują, że w kolejnym roku budżetowym, zgodnie z treścią art. 217 ust. 2 pkt 8 u.f.p., jako przychód będą stanowiły potencjalne źródło finansowania budżetu województwa samorządowego.

Kolejnym przykładem są także środki otrzymane z tytułu opłat i kar pieniężnych przewidzianych przez przepisy ustawy o drogach publicznych ${ }^{14}$. Dochody otrzymane na podstawie art. $20 \mathrm{~d}$ ust. $1 \mathrm{i}$ art. 40a ust. 1d-1 u.d.p. stanowią dochód budżetu j.s.t. Według art. 20d dochody uzyskane z grzywien ujawnionych za pomocą urządzeń rejestrujących j.s.t. w całości przeznaczają na finansowanie zadań wymienionych $w$ art. 20d. Są to między innymi zadania inwestycyjne, modernizacyjne lub remontowe związane z siecią drogową, zadania dotyczące utrzymania i funkcjonowania infrastruktury oraz urządzeń drogowych. Ustawodawca celowe przeznaczenie, zgodnie z art. 40a ust. 1, przewiduje również dla gminnych dochodów otrzymanych $z$ opłat za postój pojazdów samochodowych w śródmiejskiej strefie płatnego parkowania w wysokości nie mniejszej niż $65 \%$ tych opłat oraz środków z opłat dodatkowych, o których mowa w art. 13f ust. 1, pobranych z tytułu nieuiszczenia opłaty, o której mowa w art. 13 ust. 1 pkt 1 lit. b ustawy. Dochody z tych źródeł gmina przeznacza wyłącznie na sfinansowanie poprawy publicznego transportu zbiorowego, budowę lub przebudowę infrastruktury pieszej lub rowerowej lub zieleń i zadrzewienie w gminie. Według art. 40a ust. 1e środki pochodzące ze wskazanych tytułów gmina gromadzi na wydzielonym rachunku. Nadwyżka na rachunku bieżącym budżetu środków pieniężnych pochodzących z opłat wskazanych $\mathrm{w}$ art. $20 \mathrm{~d}$ ust. $1 \mathrm{i}$ art. $40 \mathrm{a}$ ust. $1 \mathrm{~d}-1$ u.d.p. będzie w następnym roku traktowana jako źródło przychodu w rozumieniu art. 217 ust. 2 pkt 8 . W publicystyce wskazuje się także jeszcze inne ustawy, w których występują szczególne zasady wykonywania budżetu. Mianowicie wskazuje się dochody pozyskiwane z opłat uiszczanych przez operatorów i przewoźników za korzystanie z przystanków lub dworców będących własnością j.s.t., o których mowa w art. 16 ust. 4 i 7 ustawy o publicznym transporcie zbiorowym ${ }^{15}$. Opłaty te, zgodnie z art. 16 ust. 7 ustawy j.s.t., mają obowiązek przeznaczać na utrzymanie przystanków komunikacyjnych oraz dworców, a także realizację zadań określonych w art. 18 ustawy, w wypadku gdy ich organizatorem jest gmina.

Do tej grupy zalicza się także wpływy z tytułu opłaty produktowej i dodatkowej opłaty produktowej, które na podstawie art. 38 ustawy o gospodarce opakowaniami i odpadami opakowaniowymi stanowią dochód budżetu województwa

14 Ustawa z dnia 21 marca 1985 roku o drogach publicznych, tekst jedn. Dz.U. z 2018 r. poz. 2068 ze zm., dalej: u.d.p.

15 Ustawa z dnia 16 grudnia 2010 roku o publicznym transporcie zbiorowym, tekst jedn. Dz.U. z 2019 r. poz. 2475. 
samorządowego ${ }^{16}$. W myśl art. 38 ust. 1 ustawy marszałek województwa prowadzi odrębny rachunek bankowy w celu gromadzenia i przekazywania wpływów z tytułu opłaty produktowej oraz dodatkowej opłaty produktowej. Wpływy z tytułu opłaty produktowej oraz dodatkowej opłaty produktowej w wysokości $10 \%$ stanowią dochody budżetu samorządu województwa z przeznaczeniem na koszty egzekucji należności z tytułu opłaty produktowej oraz dodatkowej opłaty produktowej i obsługę administracyjną systemu tych opłat.

Również uchwalona ustawa o funduszu dróg samorządowych wskazuje, że j.s.t. mogą otrzymać dofinansowanie lub finansowanie zadań z funduszu dróg samorządowych ${ }^{17}$. Na podstawie art. 4 ust. 1 ustawy wskazane zostały zadania, na które muszą być przeznaczone środki finansowe z tego państwowego funduszu. Między innymi są to zadania polegające na:

- budowie, przebudowie lub remoncie dróg powiatowych, zwane dalej ,zadaniami powiatowymi", lub budowie, przebudowie lub remoncie dróg gminnych, zwane dalej ,zadaniami gminnymi”;

— budowie mostów lokalizowanych w ciągach dróg wojewódzkich, dróg powiatowych lub dróg gminnych, zwane dalej „zadaniami mostowymi”;

— budowie, przebudowie lub remoncie dróg wojewódzkich, dróg powiatowych lub dróg gminnych o znaczeniu obronnym, zwane dalej ,zadaniami obronnymi”.

Środki otrzymane $\mathrm{z}$ tego państwowego funduszu celowego, zgodnie z art. 19 ustawy, nie stanowią dotacji w rozumieniu art. 126 u.f.p. Mają one jednak ściśle oznaczone przeznaczenie, właściwe dla finansowania funduszowego ${ }^{18}$. Biorąc pod uwagę, że zdania inwestycyjne związane z budową lub przebudową dróg mają często charakter wieloletni, może wystąpić różnica pomiędzy wysokością dochodów przekazanych j.s.t. a wysokością wydatków przypadających do sfinansowania w danym roku budżetowym. W świetle obecnego brzmienia art. 217 ust. 2 pkt 8 u.f.p. należy wyraźnie stwierdzić, że także i te dochody, otrzymane przez budżety j.s.t. w wypadku wystąpienia nadwyżki przekazanych dochodów nad zrealizowanymi wydatkami w konkretnym roku budżetowym, będą stanowiły w kolejnym budżecie jego przychód pochodzący z niewykorzystanych środków pieniężnych na rachunku bieżącym budżetu.

W tym miejscu należy jednak wyrazić wątpliwość, w świetle art. 31 ust. 3 tej ustawy, czy dochody pochodzące z funduszu dróg samorządowych niewykorzystane w konkretnym roku budżetowym będą mogły być rzeczywiście przeznaczone na finansowanie deficytu budżetowego j.s.t w kolejnym roku. Oznaczałoby

16 Ustawa z dnia 13 czerwca 2013 roku o gospodarce opakowaniami i odpadami opakowaniowymi, tekst jedn. Dz.U. z 2019 r. poz. 542 ze zm.

17 Ustawa z dnia 23 października 2018 roku o funduszu dróg samorządowych, Dz.U. z 2018 r. poz. $2161 \mathrm{ze} z \mathrm{zm}$.

18 Zob. M. Ofiarska, Z. Ofiarski, Fundusz dróg samorzadowych Komentarz, Warszawa 2020, s. 219-229. 
to faktyczne wykorzystanie tych środków niezgodnie z przeznaczeniem, kreując tym samym obowiązek zwrotu takich środków do funduszu wraz z odsetkami w wysokości określonej, jak dla zaległości podatkowej, w terminie 15 dni od dnia stwierdzenia takiej okoliczności.

Dyskusyjne jest również zaliczenie ustawy o pomocy społecznej do katalogu ustaw przewidujących szczególne zasady wykonywania budżetu ${ }^{19}$. Mianowicie dochody z opłat wymienionych w art. 62 u.p.s., wnoszone przez zobowiązane osoby do kasy lub na rachunek bankowy gminy, mają być według art. 61 ust. 2 pkt 3 u.p.s. przekazane na rachunek bankowy właściwego domu pomocy społecznej w celu przeznaczenia ich na utrzymanie takiego domu. Nie wszystkie regionalne izby obrachunkowe podzielają pogląd o powiązaniu dochodów ze wskazanych tytułów z konkretnymi wydatkami, o których mowa w art. 61 ust. 2 pkt 3 u.p.s. Uzasadnieniem takiego poglądu jest fakt, że zadanie wskazane w powołanym artykule należy do zadań własnych gminy, a wysokość opłaty nie jest ustalana adekwatnie do kosztów pobytu osoby w domu pomocy społecznej.

Brakiem wyraźnego powiązania dochodów z wydatkami uzasadnia się również niezaliczenie do omawianego katalogu środków, o których mowa w ustawie o lecznictwie uzdrowiskowym, uzdrowiskach i obszarach ochrony uzdrowiskowej oraz gminach uzdrowiskowych stanowiących dochód pochodzący z opłaty uzdrowiskowej otrzymywanej na podstawie art. 48 tej ustawy ${ }^{20}$. Gmina uzdrowiskowa, w celu realizacji zadań, o których mowa w art. 46, ma prawo do pobierania opłaty uzdrowiskowej na zasadach określonych w odrębnych przepisach. Zasadny jest podnoszony argument, że ustawodawca nie wskazał tutaj imiennie wymienionych wydatków, na które środki pieniężne pochodzące z tej opłaty uzdrowiskowej mogą być przeznaczone.

W grupie rozszerzającej katalog źródeł przychodów, które mogą być przeznaczone na finansowanie deficytu budżetu j.s.t., ustawa w art. 217 ust. 2 pkt 8 u.f.p. wymieniła również środki określone w art. 5 ust. 1 pkt 2 u.f.p. i dotacje na realizację programu, projektu lub zadania finansowanego z udziałem tych środków. Chodzi o środki pochodzące z budżetu Unii Europejskiej oraz niepodlegające zwrotowi środki z pomocy udzielanej przez państwa członkowskie Europejskiego Porozumienia o Wolnym Handlu (EFTA). Środki te z mocy ustawy oraz zawartych umów międzynarodowych są bezzwrotne i zawsze mają charakter celowy. Służą finansowaniu konkretnych zadan, programów lub projektów finansowanych z ich udziałem. Ta grupa środków publicznych stanowi bardzo zróżnicowaną mozaikę z punktu widzenia charakteru finansowoprawnego oraz prawnej formy, w jakiej środki te do budżetów j.s.t. mogą być przekazywane. J.s.t. mogą je mianowicie otrzymywać jednorazowo lub w transzach, w prawnej formie płatności lub zalicz-

19 Ustawa z dnia 12 marca 2004 roku o pomocy społecznej, tekst jedn. Dz.U z 2019 r. poz. $1507 \mathrm{ze}$ zm.

20 Ustawa z dnia 28 lipca 2005 roku o lecznictwie, uzdrowiskach i obszarach ochrony środowiskowej oraz gminach uzdrowiskowych, tekst jedn. Dz.U. z 2017 r. poz. 1056 ze zm. 
ki, a także w dotacji celowej na finansowanie programów, projektów lub zadań finansowanych z udziałem bezzwrotnych środków europejskich. Nowa redakcja art. 217 ust. 2 pkt 8 u.f.p. w odniesieniu do bezzwrotnych środków europejskich oznacza, że wynikające $\mathrm{z}$ nich rozliczenia na koniec okresu sprawozdawczego powinny zwiększyć przychody finansujące deficyt budżet j.s.t. Wydaje się jednak, że w wypadku projektów i programów finansowanych z udziałem środków określonych $\mathrm{w}$ art. 5 ust. 1 pkt 2 u.f.p. warto byłoby zastanowić się, czy procedury określone w umowie międzynarodowej lub inne procedury obowiązujące przy ich wykorzystaniu umożliwiają wykorzystanie powstałej nadwyżki z tych źródeł do wykorzystania celu wskazanego w art. 217 ust. 3 pkt 8 u.f.p. Nie możemy zapominać, że w wypadku finansowania projektów i programów finansowanych z udziałem wskazanych środków zastosowanie mają dwa reżimy prawne: wewnętrzny oraz określony w treści umowy międzynarodowej.

Poza przedmiotem rozważań pozostała kwestia głównej przyczyny wyodrębnienia przychodów, o której mowa w art. 217 ust. 2 pkt 8 u.f.p., to jest zmiany zasady bilansowania budżetu bieżącego, o której mowa w art. 242 u.f.p. Pominięcie tej kwestii wynika z faktu, że zmiana równoważenia budżetu w części operacyjnej będzie miała zastosowanie po raz pierwszy dopiero do budżetu j.s.t. i do wieloletniej prognozy finansowej opracowywanej na 2022 rok.

\section{ZMIANY KLASYFIKACJI BUDŻETOWEJ}

Jak już wskazano, zgodnie z art. 8 ust. 1 ustawy nowelizacyjnej przepisy art. 217 u.f.p. w obecnym brzmieniu miały zastosowanie po raz pierwszy do opracowania i wykonania budżetu j.s.t. na rok 2020. Wymagało to jednak, aby już w 2019 roku dokonane zostało rozdzielenie i rozliczenie przepływów budżetowych zaliczanych do środków pieniężnych według właściwych rodzajów przychodów budżetu. Dlatego należało dokonać koniecznych zmian w klasyfikacji budżetowej. Minister finansów w dniu 16 lipca 2019 roku wydał rozporządzenie, w którym uwzględniając zmianę przepisów u.f.p., wprowadził nowe paragrafy zarówno po stronie wydatków, jak i przychodów ${ }^{21}$. W załączniku nr 5 zawierającym paragrafy przychodowe, ze względu na zmieniony przepis art. 217 ust. 2 pkt 7 i 8 u.f.p. rozszerzający źródła finansowania deficytu budżetu j.s.t., wyodrębniono trzy nowe paragrafy przychodowe określające źródła finansowania wskazane w znowelizowanym art. 217 u.f.p., a mianowicie:

— $§, 905$ — przychody j.s.t. z niewykorzystanych środków pieniężnych na rachunku bieżącym budżetu wynikających z rozliczenia dochodów i wydatków

${ }^{21}$ Rozporządzenie z dnia 16 lipca 2019 roku zmieniające rozporządzenie w sprawie szczegółowej klasyfikacji dochodów, wydatków, przychodów i rozchodów oraz środków pochodzących ze źródeł zagranicznych, Dz.U. z 2019 r. poz. 1363 ze zm. 
nimi finansowanych związanych ze szczególnymi zasadami wykonywania budżetu określonymi w odrębnych ustawach";

— $§, 906$ — przychody j.s.t. z wynikających z rozliczenia środków określonych w art. 5 ust. 1 pkt 2 ustawy o finansach publicznych i dotacji na realizację".

W wyniku tej nowelizacji „§ 957 - nadwyżki z lat ubiegłych” otrzymał objaśnienie, z którego wynika, że j.s.t. w tym paragrafie wykazują niewykorzystane środki pieniężne pochodzące $\mathrm{z}$ nadwyżek budżetów $\mathrm{z}$ lat ubiegłych pomniejszone o środki, o których mowa w art. 217 ust. 2 pkt 8 u.f.p. Oznacza to, że nadwyżki przekazanych dochodów nad zrealizowanymi wydatkami wynikające $\mathrm{z}$ ustaw związanych ze szczególnymi zasadami wykonania budżetu, o których mowa w art. 217 ust. 2 pkt 8 u.f.p. — począwszy od 2020 roku — będą klasyfikowane w paragrafach dotyczących przychodów j.s.t. z niewykorzystanych środków pieniężnych na rachunku bieżącym budżetu, wynikających z rozliczenia dochodów i wydatków nimi finansowanych związanych ze szczególnymi zasadami wykonywania budżetu określonymi w odrębnych ustawach (§905) oraz z rozliczenia środków określonych w art. 5 ust. 1 pkt 2 u.f.p. i dotacji na realizację programu, projektu lub zadania finansowanego z udziałem tych środków (§ 906).

Ustalona obecnie konieczność indywidualizacji poszczególnych źródeł przychodów musi być także zabezpieczona w systemie rachunkowo-księgowym, co będzie wiązało się z koniecznością zmiany także w zakresie zakładowych planów kont.

\section{KONKLUZJE}

Zaproponowane zmiany treści u.f.p. w analizowanym zakresie generalnie należy ocenić pozytywnie - kreują bowiem nowe potencjalne źródła finansowania deficytu budżetu j.s.t. Umożliwiają także oddzielenie niewykorzystanych z tytułu rozliczeń rocznych środków w ogólnym rozliczeniu budżetu j.s.t. i ułatwiają tym samym rozliczenia budżetowe oraz realną kontrolę gospodarki finansowej j.s.t., również na poziomie sprawozdawczym. Zwiększenie i uporządkowanie katalogu przychodów, które mogą finansować deficyt budżetu j.s.t. oraz szczególny sposób ich ustalania, jest próbą zwiększenia transparentności gospodarki finansowej j.s.t. Może także ograniczać (często stosowany w praktyce) proceder przeszacowywania potrzeb pożyczkowych budżetu j.s.t.

Z uwagi na zróżnicowane stanowisko organów nadzoru co do zakresu przedmiotowego katalogu ustaw przewidujących szczególne zasady wykonania budżetu zasadny wydaje się postulat, aby w konkretnych uchwałach budżetowych na podstawie art. 212 ust. 1 pkt 8 u.f.p. zostały określone rodzaje dochodów/przychodów, do których będzie miał zastosowanie art. 217 ust. 2 pkt 8 u.f.p.

Niepokojący jednocześnie jest fakt, że w ostatnich latach bardzo wzrosła liczba ustaw przewidujących szczególne zasady wykonania budżetu, ograniczających de facto sposób finansowania zadań przez j.s.t. Oznacza to faktyczne zmniejszenie 
w aspekcie wydatkowym zakresu samodzielności finansowej j.s.t. To nie organ stanowiący, lecz ustawodawca decyduje bowiem o źródle finansowania zadań samorządowych. Jest to bardzo niepokojący proces. Pozostaje on w wyraźnej sprzeczności z art. 42 ust. 2 u.f.p., kreującym zasadę jedności materialnej jako jednej z podstawowych zasad gospodarki budżetowej realizowanej przez jednostki sektora finansów publicznych.

\title{
EXTENSION OF SOURCES TO FINANCE THE BUDGET DEFICIT OF TERRITORIAL SELF-GOVERNMENT UNITS
}

\author{
Summary
}

The normative notion of budget deficit in territorial self-government units (TSU) has been expressis verbis defined in article 217 section 1 of the public finance act. According to this regulation, it is the negative difference between incomes and expenses in a given budgetary year. At the same time, the legislator requires that in any budget resolution that predicts a deficit in a given year, the sources of its financing should be indicated. Therefore not only the magnitude of the TSU budget deficit, together with the ways of raising the financial means to create this deficit, are subject to legal restrictions, but also sources and ways of financing themselves. The Act of December 14th, 2018 that includes amendments to the public finance act, has introduced a number of changes to the TSU financial system, including also an extended catalogue of sources that finance the deficit. The subject of this article is to assess some important part of the introduced changes, namely those that deal with these new sources of financing the TSU budget deficit. The most essential role in this context will be played by revenues from "unused financial means in the current account of the budget, that result from the settlements of incomes and financed by these incomes expenditures, connected with specific rules of budget execution defined in separate acts". The terms "specific rules of budget execution" has not been defined by the legislator, similarly no "separate acts" have been pointed out. It is therefore essential to solve these matters. In the article, the catalogue of such acts has been given as an example. These findings will be of essential importance for further applications of the amended public finance act.

Keywords: budget incomes of self-government units, budget receivables of self-government units, budget deficit, deficit financing sources, free resources in budgetary records

\section{BIBLIOGRAFIA}

Ofiarska M., Ofiarski Z., Fundusz dróg samorządowych Komentarz, Warszawa 2020.

Walczak P., Woźniak M., Zmiany w finansach publicznych 2019, Warszawa 2019. 